\title{
Simply Impossible: A Case against Divine Simplicity
}

\author{
R. T. Mullins \\ University of Notre Dame, South Bend, IN, USA \\ rtmullins@gmail.com
}

\begin{abstract}
Within contemporary philosophical theology the doctrine of divine simplicity has regained attention. ${ }^{1}$ The pertinent literature has increased by several new defenses of the doctrine. ${ }^{2}$ One of the more surprising, and troubling, aspects of the contemporary defenses amongst Christian philosophers and theologians is a seeming lack of understanding about how radical the doctrine of divine simplicity truly is. As such, I wish to do a few things in this paper. First, systematically articulate the doctrine of divine simplicity. Second, argue that divine simplicity is not a possible perfection. Third, offer some concluding remarks and highlight remaining issues that will need to be sorted out for the debate over simplicity to meaningfully continue.
\end{abstract}

Keywords

simplicity, immutability, timelessness, freedom, modality

\section{What is Divine Simplicity?}

Divine simplicity is part of a package of divine perfections that includes timelessness and immutability. One cannot have divine simplicity without timelessness and immutability. I will place the doctrine of divine simplicity within the context of these attributes as well as the traditional views on time for the sake of gaining a better understanding of the doctrine and its systematic connections with other areas of Christian thought. The Medieval theologians and

1 Thanks to the following people for helpful discussion on earlier versions of this paper. Shawn Bawulski, Gijsbert van den Brink, Brandon Craft, Jennifer Allen Craft, Brian Hutchinson, Alan Torrance, J.T. Turner, Leigh Vicens, and two anonymous reviewers.

2 Jeffrey Brower, 'Making Sense of Divine Simplicity,' in Faith and Philosophy 25 (2008). Stephen Holmes, 'Something Much too Plain to Say: Towards a Defense of the Doctrine of Divine Simplicity,' NZSTH 43 (2001). Christopher Franks, 'The Simplicity of the Living God: Aquinas, Barth, and Some Philosophers,' Modern Theology 21 (2005). James E. Dolezal, God Without Parts: Divine Simplicity and the Metaphysics of God's Absoluteness (Eugene: Wipf and Stock Publishers, 2011). 
philosophers understood the necessary systematic connections between these attributes, but, as I will discuss below, it is not clear that many contemporary thinkers fully grasp this.

First, I shall begin with 'time.' Traditionally, most theologians and philosophers have held to a relational theory of time where time just is change. If you have a change you have time. If no change occurs, no time occurs. Also, most theologians have traditionally held to presentism - a thesis on the ontology of time where only the present exists, the past no longer exists, and the future does not yet exist. ${ }^{3}$

What does it mean to say that God is timeless? Necessarily, God is timeless if and only if He exists without beginning, without end, and without succession or moments in His life. God's life has no before or after. He does not endure through time. He does not have past moments that no longer exist, nor does $\mathrm{He}$ wait in anticipation for future moments to come into existence like temporal creatures do. Instead, God inhabits a timeless present. Further, God lacks any temporal location or extension.

What does it mean to say that God is immutable? Necessarily, God is immutable if and only if He cannot undergo any intrinsic or extrinsic change. In Sentences I, Distinction XXXVII.7, Peter Lombard explains how things change according to time.

But to change through time is to become different according to their interior or exterior qualities which are in the very thing that is changed, as when it undergoes a vicissitude of joy, suffering, knowledge, forgetfulness, or a change of form or of some other exterior quality. For this change which happens according to time is a change of qualities which happens in the bodily or spiritual creature, and so it is called time.

Any kind of change, intrinsic or extrinsic, will make an object temporal. Lombard holds that God is timeless and immutable, and as such He cannot undergo

3 See Robert Pasnau, 'On Existing All at Once,' in eds. Christian Tapp and Edmund Runggaldier, God, Eternity, and Time (Surrey, Ashgate Publishing Limited, 2011). Also, Anselm, Proslogion 13 and 22; Gregory of Nyssa, Against Eunomius I.42; Augustine, City of God XI.21 and Confessions XI. For a discussion of Augustine's puzzles over 'the present' see Richard Sorabji, Time, Creation and the Continuum: Theories in Antiqity and the Early Middle Ages (London: Gerald Duckworth \& Co. Ltd., 1983), 29-32; J.R. Lucas, A Treatise on Time and Space (London: Methuen and Co. Ltd., 1973), chapter 4; Boethius, Trinity is One God Not Three Gods, IV; Thomas Aquinas, Quaestiones Disputatae De Veritate QII.12; Rory Fox, Time and Eternity in Mid-Thirteenth-Century Thought (Oxford: Oxford University Press, 2006), 134ff. 
any intrinsic changes. ${ }^{4}$ Further, he holds that God cannot undergo any extrinsic change. ${ }^{5}$ For instance, when temporal creatures refer to God it would seem that God would undergo an extrinsic change and thus Himself be temporal. ${ }^{6}$ When a human worships God and says, 'You are my Creator and Redeemer' she is predicating an accidental property of God. Lombard, like most medieval Christian theologians, understands this, so he follows Augustine by holding that the accidental properties that creatures predicate of God do not apply to God but only befall the creature. ${ }^{7}$ The take-away from this is that to be in time is to undergo intrinsic and extrinsic change. To be timeless is to undergo no changes whatsoever. 8

What does it mean to say that God is simple? James E. Dolezal explains as follows. 'Though the doctrine has numerous positive implications for one's understanding of God's existence and essence... it is formally articulated apophatically as God's lack of parts and denies that he is physically, logically, or metaphysically composite.'9 Peter Lombard offers the following definition of divine simplicity. 'The same substance alone is properly and truly simple in which there is no diversity or change or multiplicity of parts, or accidents, or of

4 Sentences I, Dist. VIII. Also, Augustine makes the same connection. In The Trinity IV 'For God's essence, by which he is, has absolutely nothing changeable about its eternity or its truth or its will.' Later on, in V.2, he says God should be understood as 'wholly everywhere without place, everlasting without time, without any change in himself making changeable things, and undergoing nothing.'

5 Paul Helm agrees. The relevant sense of immutability needed to maintain divine timelessness must deny any kind of change, including mere 'Cambridge' change). Helm, Eternal God: A Study of God Without Time, Second Edition (New York: Oxford University Press, 2010), 19. It should be noted that divine temporalists like Thomas Morris, John Feinberg, and myself have offered weaker doctrines of divine immutability. The divine temporalist is happy to concede that these weaker doctrines of divine immutability are not compatible with divine simplicity and timelessness.

6 Nicholas Wolterstorff, Inquiring About God: Selected Essays (New York: Cambridge University Press, 2010), 153 .

7 See Sentences I, Dist. XXII, XXX, and XXXIX. Aquinas offers a similar treatment in Summa Contra Gentiles II.12.

8 Anselm agrees that God cannot undergo any change, but he allows for some accidental predicates to be said of God. He does not think that all accidental predicates would change God. Monologion 25. Yet, he is assuming that such accidents are not really properties at all since they do not really bring about a change. Brian Leftow concurs in 'Eternity and Immutability', in ed. William E. Mann The Blackwell Guide to the Philosophy of Religion (Oxford: Blackwell Publishing, 2005). Leftow and Anselm both have in mind 'Cambridge change,' and both deny that Cambridge changes are in fact changes.

9 Dolezal, God Without Parts, 31. 
any other forms. ${ }^{10}$ A standard account of divine simplicity in the contemporary literature looks as follows. ${ }^{11}$

1) God cannot have any spatial or temporal parts.

2) God cannot have any intrinsic accidental properties.

3) There cannot be any real distinction between one essential property and another in God's nature.

4) There cannot be a real distinction between essence and existence in God.

Before delving into these theses it would be good to have an understanding of 'real' distinction. In the Middle Ages it was common to hold that things can be really distinct or conceptually distinct. To say that there is a real distinction between something A and something B is to say that there is an extramental feature in reality that makes them distinct. For instance, there is a real distinction between a glass and the water it contains. A real distinction is contrasted with a conceptual distinction. To say that two things are conceptually distinct is to say that there is no extramental feature in reality that makes them distinct. The distinction exists in one's mind only. For instance, one might say that Clark Kent and Superman are distinct, but in reality this distinction exists in one's mind only since Clark Kent is the same person as Superman. In other words, Clark Kent is identical to Superman. Towards the end of the Middle Ages, John Duns Scotus introduced a formal distinction which is a kind of distinction that lies between real and conceptual distinctions. To say that two things are formally distinct is to say that there is some extramental feature in reality that makes them distinct, yet they are coextensive and inseparable. ${ }^{12}$ With this in mind we can return to the set of theses noted above.

10 Lombard, Sentences I, Dist. VIII.3. Lombard is explicitly following several Christian theologians: Augustine, Hilary of Pointers, Boethius, and Jerome.

11 Kevin Timpe, 'Truth Making and Divine Eternity', Religious Studies 43 (2007), 299. Eleonore Stump, Aquinas (New York: Routledge, 2003), 96-7. Jeffrey E. Brower, 'Simplicity and Aseity', in eds. Thomas P. Flint and Michael C. Rea, The Oxford Handbook of Philosophical Theology (New York: Oxford University Press, 2009), 105. Brian Davies, 'Simplicity', in eds. Charles Taliaferro and Chad Meister, The Cambridge Companion to Christian Philosophical Theology (New York: Cambridge University Press, 2010), 37-40.

12 Richard Cross, Duns Scotus on God (Burlington: Ashgate Publishing, 2005), 108-9. John F. Wipple, 'Metaphysics,' in ed. Norman Kreztmann and Eleonore Stump, The Cambridge Companion to Aquinas (Cambridge: Cambridge University Press, 1993). Scott MacDonlad, 'The Divine Nature,' in ed. Eleonore Stump and Norman Kreztmann, The Cambridge Companion to Augustine (Cambridge: Cambridge University Press, 2001). 
The big idea behind ( 1 ) is that God does not have any physical or metaphysical complexity. The assumption is that in order to be spatial a thing must have physical parts. God is immaterial, so God does not have any physical parts. What about temporal parts? The concept of temporal parts is tricky here. What we would call temporal parts in our day is not the same concept. ${ }^{13}$ During the Middle Ages it was common to distinguish between an endurant object and the life of the object. The object endures through time and can be properly said to exist as a whole, or all at once, in the present. The present is the only moment that exists, so an endurant object does not have parts lying about at other times. Yet, we can draw a conceptual distinction and say that the endurant object has a 'before' and 'after' in its life. Its life can be conceptually divided up into parts. ${ }^{14}$ Yet even conceptual distinctions are repugnant to divine simplicity. As Anselm explains, 'what either actually or conceptually has parts can be divided into parts, and this is altogether foreign to God. ${ }^{15}$ When classical theologians deny that God has temporal parts, this is what they have in mind. They are asserting that God has no before and after in His life because He has no moments in His life at all. On their understanding, this makes God a truly permanent entity.

If conceptual distinctions cannot even be applied to a simple God, it would seem that Christian theology is a non-starter. This can be seen in the way theologians are forced to talk when trying to be consistent with the doctrine of divine simplicity. Say you have a theological puzzle, any puzzle you like. In order to remove the puzzle one must offer a careful distinction in God. Perhaps one will need to distinguish between God's act and thought. Or maybe one needs to distinguish between God's permissive and active will. It does not really matter. In practice divine simplicity forces the theologian to say something rather embarrassing. After the theologian has spent dozens of pages making careful distinctions in God to remove the paradox she must admit that

13 For the contemporary understanding see Katherine Hawley, How Things Persist (Oxford: Oxford University Press, 2001).

14 See Robert Pasnau, Metaphysical Themes: 1274-1689 (London: Oxford University Press, 2011), chapter 18. Also, Richard Cross, Duns Scotus on God, 122.

15 Incarnation of the Word, VII. Avicenna concurs that even conceptual distinctions are foreign to the simple God. Jon McGinnis, 'Avicenna (Ibn Sina)', in eds. Graham Oppy and Nick Trakakis, The History of Western Philosophy of Religion Volume 2: Medieval Philosophy of Religion (Durham: Acumen Publishing, 2009), 64. Compare a similar statement made by James Arminius in his 25 Public Disputations, Disputation IV.XI 'Simplicity is a pre-eminent mode of the Essence of God, by which he is void of all composition, and of component parts whether they belong to the senses or to the understanding.' James Nichols trans. The Works of James Arminius: The London Edition, Volume 2 (Grand Rapids: Baker Book House, 1986), 115. 
her distinctions exist in her mind only. They do not apply to God at all. ${ }^{16}$ In other words, she has just committed all of her work to the flames. ${ }^{17}$ But ignore this problem for the moment in order to move to point 2 , above.

(2) appears to allow God to undergo extrinsic change, but as noted above, classical theologians have already denied this possibility of God in the doctrine of divine timelessness and immutability. This is important to note since several contemporary defenders of divine simplicity have ignored this. For instance, Eleonore Stump and Norman Kretzmann claim that a simple God cannot be exempt from having extrinsic accidental properties. ${ }^{18}$ What they have in mind are properties like being referred to. This is completely contrary to the doctrine of God as spelled out by classical theologians. Augustine, Boethius, Lombard, and Aquinas all deny extrinsic accidental properties of God. Standard examples are things like Creator, Redeemer, and Lord. James Arminius adds Judge of all men to the list as well. For these theologians God cannot have these accidental predicates because that would entail that God came to have them, and thus He would be mutable, temporal and not simple. Classical theologians held that we can refer to God, but that we must realize that our accidental predicates only befall us and not God. ${ }^{19}$ In allowing extrinsic accidental properties to apply to God, Stump and Kretzmann have failed to see how truly radical the doctrine of divine simplicity is. They have also failed to see the systematic connections between simplicity, immutability, and timelessness.

Of course, they do admit that they are weakening the claims of divine simplicity. ${ }^{20}$ What Stump and Kretzmann seemed to have missed, however, is that divine simplicity is a determinate concept that cannot be weakened

16 For moves of this sort see John Philoponus, Against Proclus on the Eternity of the World 1-5, translated by Michael Share (London: Gerald Duckworth \& Co. Ltd., 2004), 62. Thomas Aquinas, Quaestiones Disputatae de Veritate QII.14. James Arminius, Disputation IV.XI. Katherin Rogers, Perfect Being Theology (Edinburgh: Edinburgh University Press, 2000), 31-8. Nicholas of Cusa uses simplicity and infinity to argue that there is no difference between Christian belief in the Trinity and the Jewish and Islamic denial of the Trinity. See Jasper Hopkins, 'Nicholas of Cusa', in The History of Western Philosophy of Religion Volume 2, 243.

17 For more on this see my 'Divine Perfection and Creation,' The Heythrop Journal (forthcoming).

18 Eleonore Stump and Norman Kretzmann, 'Absolute Simplicity,' Faith and Philosophy 2 (1985), 354 .

19 Augustine, The Trinity V.17. Boethius, The Trinity Is One God Not Three Gods IV. Peter Lombard, Sentences Book I Dist. XXX.1. Aquinas, Summa Contra Gentiles II.12. Arminius, Disputation IV.XIV.

20 See, 'Absolute Simplicity,' 369, and their 'Simplicity Made Plainer,' Faith and Philosophy 4 (1987). For a critique of their move see Katherin Rogers, 'The Traditional Doctrine of Divine Simplicity,' Religious Studies 32 (1996). 
without destroying all of the other elements of the doctrine. If we allow for God to have an accidental property we have (i) said that God has properties, (ii) said that God has accidental properties, (iii) introduced diversity in God, and (iv) introduced potential into God since there are other ways He can be. In other words, we have abandoned the basic claims of divine simplicity as well as undermined timelessness and immutability. As such, any proponent of divine simplicity cannot make this move.

(4) comes straight out of the mouth of Thomas Aquinas in his Summa Theologiae I.Q3.a4, and similar statements can be found in Anselm and Augustine. The claim that God's essence is identical to His existence is taken to be part of what makes God unique from creatures. Of course, one might wonder what this means. This will become clear when one understands (3). There can be no real distinction in God's attributes because the attributes are all identical to each other and identical to God.

Sometimes divine simplicity is taken to be that all of the essential divine attributes are mutually entailing. As such, one might wonder if (3) is an accurate portrayal of divine simplicity. Augustine almost seems to be saying this in several places. In The Trinity XV.7 Augustine argues that God is genuinely immortal since He never started to exist, and never can cease to exist. So, genuine immortality is unchanging. 'But that is also genuine eternity by which God is unchangeable, without beginning, without end, and consequently incorruptible. Therefore one and the same thing is being said, whether you say God is eternal or immortal or incorruptible or unchangeable.' Whether you say that God is wise, powerful, living, understanding, or beautiful, '[t]he same thing is being said.'

It is easy to see how one could get mutual entailment of the divine attributes from a statement like this, but a careful reading of Augustine shows that divine simplicity is a much stronger claim. 'But for God it is the same thing to be as to be powerful or just or wise or anything else that can be said about his simple multiplicity or multiple simplicity to signify his substance.'21 Elsewhere he makes it even clearer that divine simplicity involves (3).

God however is indeed called in multiple ways great, good, wise, blessed, true, and anything else that seems not to be unworthy of him; but his greatness is identical with his wisdom (he is not great in mass but in might), and his goodness is identical with his wisdom and greatness, and his truth is identical with them all; and with him

${ }^{21}$ The Trinity, VI.6. 
being blessed is not one thing, and being great or wise or true or good, or just simply being, another. ${ }^{22}$

This is the way Christians throughout history have understood divine simplicity. ${ }^{23}$ For instance, the 17 th Century English theologian Richard Stock notes that

it appeares, that however these things are attributed to God, that he is love, mercy, favour, and anger, howsoever they are spoken, as though they were many and different, yet in God they are but one, and the same. True it is, that we are of a compounded understanding, they are as severall things to us; because we cannot conceive God as he is, yet by faith, we are brought to beleeve that there is no such difference between them in God: that which is the love of God, is the hatred of God; and that which is his wisdome, is his power also; because there is but one and the same Essence. $[s i c]^{24}$

Stock, like so many others throughout church history, is following Augustine's moves in The Trinity.

Augustine argues throughout The Trinity that all of God's essential divine attributes are identical to each other. On divine simplicity, anything that one might predicate of God should be understood as signifying the divine substance. You could say that God is eternal, immortal, incorruptible, unchangeable, living, wise, powerful, beautiful, and so forth. Yet all of those terms signify the divine substance. They are not qualities or properties that God has because

22 The Trinity, VI.8

23 Boethius follows Augustine on the doctrine of divine simplicity. See The Trinity is One God Not Three Gods IV. See also Anselm, Monologion 16-17. Aquinas does the same throughout Summa Contra Gentiles book I. John Duns Scotus seems to be one of the few Christians to dissent from this in the Middle Ages by employing his formal distinction, but this dissent is minimal. He still claims that all of the attributes are identical and that there is no composition in God. He also continues to hold that God is pure act. See his De Primo Principio, 143-5. Arminius follows Augustine, but suggests that it might be possible to allow the formal distinction. See his Disputation IV.XI. The Socinians rejected the doctrine along with the Trinity. Samuel Clarke did not seem to be a fan of divine simplicity either, but did defend the Trinity. Rene Descartes and Baruch Spinoza accepted a traditional account of divine simplicity. Despite dissent, many in the Reformed tradition continued to hold to this conception of divine simplicity. For discussion of the Reformed tradition, see Richard Muller, Post-Reformation Reformed Dogmatics Volume 3: The Divine Essence and Attributes, 273-82. For a discussion of the doctrine in the Middle Ages and in the contemporary scene see William Vallicella, 'Divine Simplicity,' in ed. Edward N. Zalta, The Stanford Encyclopedia of Philosophy, http://plato.stanford.edu/entries/divine-simplicity/.

24 Stock, A Stock of Divine Knowledge, being a lively description of the divine nature (London: T.H. for Philip Nevil, 1641), 88. 
they are identical to God. ${ }^{25}$ Creatures have properties by participating in goodness, wisdom, life, or what have you. God, who is the greatest being, does not have goodness by participating in something else. Goodness is identical to His essence, and God is identical to His essence. So God is the Good. ${ }^{26}$ Other things have an essence and subsist, or underlie, the properties they have. Not so with the simple God. "[I]t is impious to say that God subsists to and underlies his goodness, and that goodness is not his own substance. ${ }^{27}$ As Katherin Rogers explains, the traditional doctrine of divine simplicity denies that God has any properties. 'With God we do not hypothesize any unity underlying the diversity because there is no diversity. ${ }^{28}$ Rogers claims that Plantinga style arguments against simplicity fail because they neglect this point by treating God as if $\mathrm{He}$ has properties, or is a property. ${ }^{29}$ These types of objections fail to see how truly radical divine simplicity is. ${ }^{30}$

One additional claim is needed to flesh out divine simplicity. There is one final aspect of simplicity that is sometimes overlooked in contemporary discussions: God is pure act. ${ }^{31}$ As Aquinas explains, composite things have potential. They move from potential to actual. But God is simple, so He must lack potentiality and be pure act. One example of this idea is that God just is His act of existence. ${ }^{32}$ God is not something that underlies His properties because $\mathrm{He}$ does not have any properties. God does not go from potential to actual for He is pure act. God's act is identical to God, and not something distinct. "His action

25 The Trinity, XV.8. John Duns Scotus agrees. "There is nothing in the divine that is not the same thing as the divine essence and also the same as anything essential, so that considering such in the abstract, one can say simply "This is this".' God and Creatures Q5.34.

26 The Trinity, V.11.

27 The Trinity, VII.10.

28 Katherin Rogers, 'The Traditional Doctrine of Divine Simplicity', 166, see also 173. Also, Henry Church, Miscellanea Philo-Theologica (London: I.N. for John Rothwell, 1638), 23.

29 Rogers, Perfect Being Theology, 27. The types of objections she has in mind come from Alvin Plantinga and Thomas Morris. Alvin Planinga, Does God Have a Nature? (Milwaukee: Marquette University Press, 1980).Thomas Morris, Anselmian Explorations: Essays in Philosophical Theology (Notre Dame: University of Notre Dame Press, 1987).

30 However these arguments do bring out a relevant objection that John Duns Scotus and William of Ockham both noticed and criticized Aquinas for failing to answer. Our concepts are clearly not identical to each other, and yet they are supposed to be identical in God. What do our concepts hang on? They can't apply to the simple God for there is no diversity in Him. See Richard Cross, 'John Dun Scotus' and Gyula Kilma, 'William of Ockham', in The History of Western Philosophy of Religion Volume 2.

31 See Rogers, 'The Traditional Doctrine of Divine Simplicity', for more on this. Cf. Dolezal, God Without Parts.

32 Summa Contra Gentiles, I.16-22. 
is His being...God's action is His substance." "33 "T]he manifold actions ascribed to God, as intelligence, volition, the production of things, and the like, are not so many different things, since each of these actions in God is His own very being, which is one and the same thing." 34

How does simplicity connect with eternity and immutability? As Augustine explains, 'Nothing simple is changeable; everything created is changeable.'35 Again, on a relational understanding of time, time just is change. If God is unchanging, He is timeless. A simple God has no properties. 'So there is no modification in God because there is nothing in him that can be changed or lost.'36

Further, a being who is pure act does all that He does in one timeless present. He simply is His act of thinking, willing, creating, and so on. If God went from potential to act, He would have accidental properties. But as pure act, He has no accidental properties. Since He has no accidental properties there is no worry of Him changing or persisting through time. Objects that persist through time are constantly gaining and losing accidental properties. God has no accidental properties, so- the argument goes- He is timeless.

\section{Simplicity is Not a Possible Perfection}

It would be intellectually dishonest to say that divine simplicity is obviously lying about in scripture. One would be hard pressed to say that the Bible clearly teaches it. ${ }^{37}$ Biblical claims that 'God is spirit' and 'God is love' significantly underdetermine divine simplicity and fail to bring us anywhere near the essential elements of the doctrine. Isaiah never says, 'Thus sayeth the Lord, all of my attributes are identical to each other.' Paul never writes to a church, 'This is the mystery expressed unto you: God is pure act.' Divine simplicity is derived from Greek philosophy. ${ }^{38}$ 'The view that simplicity is a perfection, implying immutability and incorruptibility, was established by the time of Parmenides and found its fullest expression in the Neoplatonic system of Plotinus. ${ }^{39}$

\footnotetext{
33 Summa Contra Gentiles, II.9.

34 Summa Contra Gentiles, II.10.

35 The Trinity, VI.8.

36 The Trinity, V.5.

37 John Feinberg, No One Like Him: The Doctrine of God (Wheaton: Crossway Books, 2001), 327-29.

38 Nicholas Wolterstorff, Inquiring About God, 108.

39 Rogers, 'The Traditional Doctrine of Divine Simplicity', 165.
} 
However, one should not reject divine simplicity on this ground alone. To reject simplicity because it is derived from Greek philosophy is to commit the genetic fallacy. Some contemporary philosophical and systematic theologians are prone to play the 'Greek card' which involves merely stating, 'Such and such a doctrine is derived from pagan Greek philosophy and not the Bible.' The Greek card is meant to be a refutation of a particular doctrine, but instead it is fallacious thinking. Something could be derived from Greek philosophy and be compatible with the Bible. Further, the Greek card is something anyone can play since much of Christian theology was developed with the tools of Greek philosophy. For instance, the doctrine of the eternal generation of the Son and eternal spiration of the Holy Spirit are clearly derived from a Neoplatonic framework and lack biblical justification. ${ }^{40}$ The Greek card can be used against this particular aspect of the traditional doctrine of the Trinity. Any theologian wishing to maintain the eternal generation of the Son ought not to use the Greek card. The origin of a doctrine is worth considering, but what is more important is whether or not the doctrine in question is compatible with scripture.

Christian theologians in the past saw that divine simplicity conflicted with a whole host of biblical claims. ${ }^{41}$ For instance, they realized that it conflicted with calling God Lord, Creator, Redeemer, and Refuge because these are all accidental properties, and accidental properties are repugnant to divine simplicity. ${ }^{42}$ They offered various ways to interpret scripture in an attempt to make it compatible with simplicity because they thought they had independent justification for the doctrine. These theologians thought simplicity was derived from the method of 'perfect being' theology. ${ }^{43}$

40 The economic sending of the Son and Spirit are found in Scripture, but not the immanent eternal generation and spiration.

41 This is not unique to Christian theology. The same is true in Jewish and Islamic theology as well.

42 This problem is noted by John of Damascus, Augustine, Lombard, Aquinas, and Scotus. For an exposition of their response and a critique see my forthcoming PhD thesis, In Search of a Timeless God.

43 Eleonore Stump, 'Eternity, Simplicity, and Presence', in eds. Christian Tapp and Edmund Runggaldier, God, Eternity, and Time (Surrey: Ashgate Publishing Limited, 2011), 36. For an argument that simplicity is not derived from perfect being theology see Thomas V. Morris, 'Dependence and Divine Simplicity,' International Journal for Philosophy of Religion 23 (1988). For an articulation of the method of perfect being theology see Jay Wesley Richards The Untamed God: A Philosophical Exploration of Divine Perfection, Simplicity and Immutability (Downers Grove: InterVarsity Press, 2003). 
Space does not allow me to delve into the entire method of perfect being theology. As such, I will only mention a few features. As one might expect, perfect being theology assumes that God is the greatest conceivable being. Katherin Rogers notes that the idea that 'God is the best seems to be taken for granted' in all of theology. ${ }^{44}$ One motivation for this assumption seems to be that only a perfect God is worthy of worship. As John of Damascus puts it, 'that which comes short of perfection, whether it be in goodness, or power, or wisdom, or time, or place, could not be God.' (Orthodox Faith I.5) Another starting assumption is that God must possess all perfections because He is the source of all perfections. ${ }^{45}$ As the source of all perfections God is not dependent upon anyone or anything for His perfection. If He did not have all of the perfections, and was not the source of all the perfections, He would not be the greatest conceivable being and would not be worthy of worship. ${ }^{46}$ Further, God's perfection is not dependent upon anything or anyone outside of Himself. This is called the Sovereignty-Aseity Conviction. ${ }^{47}$ The doctrine of divine aseity says that God's existence and essential nature do not depend upon anything outside of God. ${ }^{48}$ To say that God is sovereign is to affirm that God's will is self-determined. ${ }^{49}$ There is nothing outside of God that determines His will. God is thus perfectly free.

Christian theists have long affirmed that God is perfectly free in that nothing outside of Himself determines His will, and that God could have done otherwise. ${ }^{50}$ Several areas of Christian doctrine depend upon this notion of God's ability to do otherwise. These will be discussed further below, but, for now, a few brief comments are in order. For example, Christians have widely held that the doctrine of creation ex nihilo exemplifies the fact that God did not have to exist with creation. One of the major differences between Christian theism and panentheism is that the Christian God can exist without creation, whereas the panentheistic God must exist with creation and cannot exist without creation in order to be who He is. The Christian theologian will typically affirm that her God is worthy of worship because this God's perfection and

\footnotetext{
44 Katherin Rogers, Perfect Being Theology (Edinburgh: Edinburgh University Press, 200o), 2. Cf. Augustine, On Christian Doctrine, I.7.

45 Thomas Aquinas, Summa Theologica I.Q4.2. See also John Harris, A Refutation of the Objections Against the Attributes of God in General (London: King's-Head, 1698).

46 Scotus, God and Creatures Q1.9.

47 Richards, The Untamed God, 33.

48 Feinberg, No One Like Him, $239 \mathrm{ff}$.

49 Ibid., 294.

50 Brower, 'Simplicity and Aseity,' Oxford Handbook of Philosophical Theology, 107.
} 
existence do not depend upon creation. Another example of the importance of God's freedom to do otherwise in Christian theology is in regards to God's grace. An essential feature of this doctrine is that God did not have to grant creatures saving grace. God did not have to become incarnate to make atonement for us. He could have refrained from doing so. If God did not have the ability to refrain from offering us grace, it is hard to see how such a thing is in fact grace.

With that being said, there are several further constraints on the method of perfect being theology that must be discussed before delving into the main argument of this paper. First, when considering an attribute that might be a perfection one must figure out if the attribute is logically and metaphysically possible. For instance, when one says that God is omnipotent one does not say that He can perform logically impossible actions. God cannot make Socrates exist and not exist at the same time. Why? It is a logically impossible state of affairs. It describes something that does not ultimately make any sense. Another example is that God's eternity cannot be a simultaneous succession. This is a metaphysically impossible state of affairs. If God has succession in His life the events must be in a before and after relation. That is what it means to have succession. If the events are simultaneous they cannot be successive. ${ }^{11}$ Second, when considering an attribute that might be a perfection one must figure out if the attribute is metaphysically compossible with who God is. Can God lie? No (Titus 1:2). He is perfectly good and lying is not compatible with His nature. Can God break a covenantal promise? No (Malachi 3). That would be incompatible with His holiness and covenant faithfulness. To say such things is not to limit God, nor does it fall into an inappropriate anthropomorphism. Instead, it is establishing what can be meaningfully said of God based on rational reflection of God's self-revelation. In other words, it is a refusal to predicate nonsense of God.

As noted above, divine simplicity has traditionally been said to be derived from the method of perfect being theology. For instance, it has been argued that it satisfies the Sovereignty-Aseity Conviction because God's essential nature does not depend upon universals that exist independently of God. As noted in the previous section, God does not have any properties so He does not participate in goodness like creatures do. His goodness is not dependent upon

51 In Kevin Vanhoozer's Remythologizing Theology: Divine Action, Passion, and Authorship (Cambridge: Cambridge University Press, 2010), 255, 319-23, and 454 he affirms that God simultaneously possesses succession such that there is no before or after in God's life. If he really means what he says, his doctrine of divine eternality is metaphysically impossible. 
something outside of Himself. It is not clear to me that simplicity is needed to satisfy the Sovereignty-Aseity Conviction. This is because arguments of this sort typically assume that there are only two options about the relationship between God and abstract objects-Platonism or divine simplicity. ${ }^{52}$ But this disjunctive is false. There are other possible models available concerning the relationship between God and abstract objects that one could hold that do not require divine simplicity to satisfy the Sovereignty-Aseity Conviction. But such a discussion must be had elsewhere. ${ }^{53}$ All that matters for my argument is that proponents of divine simplicity hold that simplicity is a perfection derived from the method of perfect being theology. I shall argue that simplicity is not a possible perfection.

If simplicity is not a possible perfection, it cannot be derived from the method of perfect being theology. As such simplicity would lack justification. Further, if simplicity is not compossible with who God is, then it is incoherent to predicate simplicity of God at all. It is my contention that divine simplicity is not a perfection because it is not metaphysically compossible with who God is. Why? The Triune God is perfectly free, and freedom, as I shall argue, is not compossible with pure act. One should recall that as pure act God has no unactualized potential. If God has any unactualized potential, He is not simple.

Before laying out my argument in full I need to make a few quick metaphysical distinctions. A state of affairs is the way things could be. For instance, Abraham Lincoln could be the 16th president of the United States of America. This is a possible state of affairs because it could happen. It is also an actual state of affairs. An actual state of affairs is a possible state of affairs, but it is different in that it obtains or is actual. A merely possible state of affairs does not obtain. A possible world is a maximal compossible totality of states of affairs. It describes the entire way things could be. For instance, there is a possible world in which God alone exists without creation. An actual world is a possible world that obtains. A merely possible world does not obtain. A universe is a spacetime continuum that is not spatially, temporally, or causally related to other spacetime continuums. Assuming that the concept of a multiverse is coherent, there is a possible world in which God creates many universes. There is also a possi-

\footnotetext{
52 Dolezal, God Without Parts, 30. Throughout his book he seems to have this assumption that one must hold either divine simplicity or fall into Platonism.

53 Keith Yandell, 'How Many Times Does Three Go Into One?' in, eds., Thomas McCall and Michael C. Rea, Philosophical and Theological Essays on the Trinity (Oxford: Oxford University Press, 2009). Also, Joseph Sternberg, 'Properties, Parts, and Parity: In Defense of Unsung Divine Territory,' (forthcoming).
} 
ble world in which God creates just one universe. With these distinctions in mind consider the following argument. ${ }^{54}$

Could God have created a different universe instead of this one? The answer seems to be 'yes,' if God is free. If God did not create a different universe, He has unactualized potential. Divine simplicity should push one to say that God did create another universe. In fact, simplicity should push one to say that God created an infinite number of universes. ${ }^{55}$ Otherwise God would not be pure act. Of course, it should be noted that God cannot create any universe that is on the whole more evil than good for that would conflict with who God is. Creating a universe where evil has the ultimate say is not compossible with a perfectly good God.

Yet even with these qualifications there is still a problem. God cannot create a world that contains our universe and another universe that contains my individual essence. My individual essence exists in this universe, so it cannot be instantiated in another universe in the actual world. He could create another universe with an essence similar to mine, but it will not be my individual essence. If there is a possible universe, different from this one, that contains my individual essence, God cannot actualize it since He has already actualized this one. As such, God has unactualized potential. There is a universe He might have created.

There is a deeper problem. Could God have refrained from creating the universe? If God is free then it seems that the answer is obviously 'yes. ${ }^{56} \mathrm{He}$ could have existed alone. Yet, God did create the universe. If there is a possible world

54 For discussion on this see Timothy O'Connor, 'Theism and the Scope of Contingency,' in ed. Jonathan Kvanvig, Oxford Studies in Philosophy of Religion: Volume 1 (Oxford: Oxford University Press, 2008). Klaas J. Kraay, 'The Theistic Multiverse: Problems and Prospects,' in ed. Yujin Nagasawa, Scientific Approaches to the Philosophy of Religion (forthcoming). Kraay, 'Creation, World-Actualization, and God's Choice Among Possible Worlds,' Philosophy Compass 3 (2008). Ross P. Cameron,' 'God Exists at Every (Modal Realist) World: Response to Sheehy,' Religious Studies 45 (2009). It should also be noted that the notion of multiple universes is an ancient concept. Aristotle, for instance, argued that there could not be more than one universe. Various Christian theologians rejected Aristotle's arguments and held that God could create multiple universes if he so desired. For instance, the 14th Century theologian and philosopher Nicole Oresme Le Livre du ciel et du Monde (London: The University of Wisconsin Press, 1968), 149-79.

55 Klaas J. Kraay, 'Theism and Modal Collapse,' American Philosophical Quaterly 48 (2011).

56 Interestingly, various Islamic philosophers in the Middle Ages were led by divine simplicity to deny that God had volition and will in regards to creation. A simple God cannot have such things because everything is done of necessity. This is one reason why Al-Ghazali rejected divine simplicity. See Ilona Kock, 'The Debate About God's Simplicity: Reason and Spirit in the Eight Discussion of Al-Ghazali's Tahafut Al-Falasifa and Ibn Rushd's Tahafut At-Tahafut,' in ed. A.T. Tymieniecka, Reason, Spirit and the Sacral in the New Enlightenment: Islamic Metaphysics 
in which God exists alone, God is not simple. He eternally has unactualized potential for He cannot undo His act of creation. He could cease to sustain the universe in existence, but that would not undo His act of creating. One could avoid this problem by allowing for a modal collapse. One could say that everything is absolutely necessary. Necessarily, there is only one possible worldthis world. Necessarily, God must exist with creation. There is no other possibility. God must create the universe that we inhabit, and everything must occur exactly as it in fact does. There is no such thing as contingency when one allows a modal collapse.

It is the case that proponents of divine simplicity sometimes acknowledge that simplicity entails that the actual world is the only possible world. This, as they note, would avoid the problem of potentiality in God. ${ }^{57}$ What is not acknowledged is that a modal collapse is odious to Christian theology for several reasons. First, it denies of God His infinite creative freedom and sovereignty over creation. Necessarily, God must exist with creation on a modal collapse. He is not free to exist without creation. This is deeply repugnant to Christian thought which holds that God is perfect in Himself and can exist without creation. ${ }^{58}$ As John Webster explains, 'the triune God could be without the world; no perfection of God would be lost, no triune bliss compromised, were the world not to exist; no enhancement of God is achieved by the world's existence. ${ }^{59}$

Second, a modal collapse from divine simplicity undermines God's aseity. In order for God to be who He is_-pure act-He necessarily must create this world. This makes God's essential nature dependent upon creation. In consistently working out the details of divine simplicity and creation, Rogers comes to this conclusion.

From God's perspective, if His essence is His eternal and immutable act in this the actual and only really possible world then He could not fail to have any of His attributes and still be Himself. They are equally necessary. That means that we are

Revived and Recent Phenomenology of Life (New Hampshire: The World Institute for Advanced Phenomenological Research and Learning, 2011), 163-67.

57 Dolezal, God Without Parts, 205-6. Rogers, The Anselmian Approach to God and Creation (Lewiston: The Edwin Mellen Press, 1997), 54 and 68-9, Perfect Being Theology, 33-6. However, in personal correspondence Rogers has stated that she recognizes the problem, and would like to figure out a way to avoid a modal collapse.

58 Some examples are John Philoponus, Against Proclus On the Eternity of the World 1-5, translated by Michael Share (London: Gerald Duckworth \& Co. Ltd., 2004), 66-8. Bonaventure, Il Sent. d.1, a.1,q.2. Thomas Aquinas, Summa Contra Gentiles I.86.

59 John Webster, 'Trinity and Creation,' International Journal of Systematic Theology 12 (2010), 12. 
forced to conclude that creatures do have some effect on God's very essence. This seems shocking since a major motivation for insisting on simplicity is the absolute aseity of God. And now we have apparently arrived at the conclusion that He is dependent on creatures! ${ }^{60}$

This being the case, divine simplicity is not compossible with God's aseity. Further, this modal collapse from divine simplicity eradicates the distinction between the God of Christian theism and the God of panentheism. The difference is supposed to be that the Christian God can exist without creation, and that His nature does not depend upon creation. But divine simplicity pushes us to a modal collapse where God must necessarily exist with creation in order to be who He is.

Third, a modal collapse completely eradicates creaturely freedom. Everything is necessary and nothing is contingent. The ramifications of this for the problem of evil, grace, God's goodness, and other areas of Christian dogmatics are disastrous. It is at this point that we can see that divine simplicity is a cruel mistress who has no tolerance for contingency and freedom. So much the worse for divine simplicity.

Perhaps one will object by saying that this type of modal thinking has no place in theology and as such cannot be used against divine simplicity. ${ }^{61}$ I find this far from obvious. The medieval theologians had no problem using modality to flesh out Christian doctrine. ${ }^{62}$ For them, modality plays an important role in how we think about the necessity and aseity of God, the contingency of creation, the freedom-foreknowledge problem, the distinction between the immanent and economic Trinity, and so on. Basic Christian doctrine cannot be explicated without modality.

For instance, the medieval Christians held that any of the divine persons could have become incarnate. ${ }^{63}$ It was possible for the Father or the Holy Spirit

60 Rogers, Perfect Being Theology, 37.

61 Michael J. Dodds, The Unchanging God of Love: Thomas Aquinas and Contemporary Theology on Divine Immutability, 2nd Edition (Washington D.C.: The Catholic University of America Press, 2008), 175-80. Oddly, Dodds claims that such counterfactual thinking has no place in theology after he articulates and endorses the medieval modal distinction between absolute and conditional necessity. If Dodds can use modality in theology, then so can I.

62 For an account of early medieval modality see Simo Knuuttila, 'Anselm on Modality,' in ed. Brian Davies and Brian Leftow, The Cambridge Companion to Anselm (Cambridge: Cambridge University Press, 2004). Reformed theologians like T.F. Torrance also stress the importance of modality for Christian theology. See his Divine and Contingent Order (Oxford: Oxford University Press, 1981).

63 Richard Cross, The Metaphysics of the Incarnation: Thomas Aquinas to Duns Scotus (Oxford: Oxford University Press, 2002), 179. 
to have become incarnate instead of the Son. Why did the Son become incarnate and not another divine person? Anselm says that we do not know why, but he offers a possible reason. If the Father or Spirit had become the economic Son, we would have two Sons in the Trinity. Such a state of affairs would be utterly confusing to human persons, so it is fitting that the immanent Son become the economic Son. ${ }^{64}$

It does not matter if one finds Anselm's reasoning persuasive. (I for one do not.) What matters for our discussion is the possibility that any of the divine persons could have become incarnate. If it is a real possibility that the Father or Spirit could have become incarnate, then this is an unactualized potential in God. As such, God is not simple.

One possible rejoinder is to say that the actual world contains a universe in which the Father becomes incarnate, and another universe in which the Spirit becomes incarnate. The Son is only incarnate in our universe. Each divine person is incarnate in the actual world, so there is no unactualized potential in God. This move, however, does not work for at least two reasons. First, the Father could have become incarnate in this universe, but He did not. So He has unactualized potential. Or the Holy Spirit could have become incarnate in this universe, but He did not. So He has unactualized potential. Second, if it is possible that none of the persons become incarnate, then this too is an unactualized potential in God. Basically, if it is possible that God does anything other than what He in fact does do, He has potential that is unactualized.

Another possible rejoinder is to say that only the Son could have become incarnate. As such, the unactualized potential of the Father and Spirit does not exist. This could avoid the problem as long as one does not mind holding to an unfortunate form of eternal subordination. To say that only the Son could have become incarnate is to say that there is an essential property, not a personal or notional property which the Son has that the other divine persons do not have. As such, the Son would not be of the same essence of the Father and Spirit. ${ }^{65}$ This avoids this particular problem for divine simplicity, but at the cost of abandoning the Trinity. Since the Trinity is essential to Christian belief, Christians cannot make this move.

A quick summary seems to be in order. I have offered three independent conflicts that arise from divine simplicity and divine freedom that render simplic-

\footnotetext{
64 Incarnation of the Word, X.

65 Thomas McCall and Keith Yandell, 'On Trinitarian Subordinationism', in Philosophia Christi $11: 2(2009)$.
} 
ity incompatible with who God is. As such, divine simplicity is not metaphysically possible given divine freedom, and cannot be a possible perfection. First, God cannot create another universe in the actual world with my individual essence in it. Thus, He has unactualized potential. Second, God cannot exist without creation. Thus, He has unactualized potential. Third, the possibility that any of the divine persons could be incarnate creates a whole host of unactualized potential in God. In order to defeat my argument one will need to offer a response to each of the three conflicts. ${ }^{66}$

\section{Concluding Remarks}

A common claim amongst contemporary theologians is that Christians must choose either the doctrine of the Trinity or the doctrine of divine simplicity. Interestingly, Islamic thinkers in the Middle Ages argued in a similar fashion against the doctrine of the Trinity. ${ }^{67}$ The objection that I laid out above reinforces these claims. However, my claim is even stronger. My contention is that divine simplicity is not even a possible perfection and as such cannot be predicated of God. It does not matter if God is triune or unitary. All that is neededto show that divine simplicity is false-is the claim that God is free. The revelation through Christ that God is three persons gives Christians further reason to reject divine simplicity because it declares that there is diversity in God. The independent conflict between simplicity and divine freedom is important since it gives Christians a way of defeating arguments against the Trinity based on divine simplicity.

Yet this is just the tip of the iceberg. It is not merely the case that divine simplicity cannot be predicated of God because it is metaphysically impossible, given God's freedom. Divine simplicity suffers from other theological woes as well. By way of conclusion I wish to mention some further difficulties that will need to be dealt with in later writings. I merely want to put them on the table so that we can be clear and honest about where the difficulties for divine

66 It should be noted that the standard Thomistic reply to objections of this sort will not work. The standard Thomist reply is to say that God wills Himself as the ultimate end of absolute necessity, but only wills creation of conditional or suppositional necessity. The reason that this does not work is because it is inconsistent with divine simplicity. On simplicity, God's act of creating is identical to His act of willing Himself, so there cannot be two different modalities at play. Otherwise, the acts are not identical, and that is repugnant to divine simplicity. This Thomistic reply has smuggled in diversity and distinctions in God-and a simple God has no diversity or distinctions.

67 G.R. Evans, Philosophy and Theology in the Middle Ages (London: Routledge, 1993), 60. 
simplicity are in hope that it will generate a better debate amongst contemporary philosophical and systematic theologians.

First, the revelation through Christ declares that God is our Creator, Redeemer, and Lord. These are accidental properties, and as such are repugnant to divine simplicity. ${ }^{68}$ The Christian should rightly be skeptical of - if not downright indignant toward-any claim that denies that these accidental properties apply to God, and yet this is exactly what simplicity explicitly entails. It also entails that God does not stand in a real relation to creation. Instead, God stands in a relation of reason that exists in our minds only and that does not apply to extramental reality. Medieval Christians were upfront about this entailment, and so should contemporary proponents of the doctrine. ${ }^{69}$ To say that God is not really related to creation is at best unintuitive, and at worst unbiblical. Defenders of divine simplicity must reconcile this with a Bible that has no qualms predicating accidental properties of a God who is intimately and radically related to creatures.

Second, there is difficulty for the incarnation. No metaphysical categories apply to a simple God. In discussing Aquinas' doctrine of the incarnation, Eleonore Stump makes it clear that divine simplicity prevents Aquinas from formulating the doctrine of the incarnation since the Aristotelian categories cannot apply to the simple God. ${ }^{70}$ Of course Aquinas does articulate the doctrine of the incarnation, but he is being inconsistent in so doing. It will not help to point out - as several recent defenses have — that classical thinkers held the incarnation and simplicity. Lots of theologians have held inconsistent views in the past, and this continues today. Just because Aquinas or John of Damascus believed in simplicity and the incarnation does not mean that those doctrines are compatible. It is one thing to believe these doctrines, and another to show that they are compatible. Anyone wishing to hold to divine simplicity must demonstrate that these doctrines are compatible. They must also deal with the communicatio idiomatum - the communication of the properties onto the

68 John Duns Scotus, De Primo Principio, 143-5. Also, Richard Stock, A Stock of Divine Knowledge, 86.

69 Augustine, The Trinity V.17. Peter Lombard, Sentences I, Dist. XXX.1. Aquinas, Summa Contra Gentiles II.12. Jeffrey Brower, 'Medieval Theories of Relations,' Standford Encyclopedia of Philosophy, http://plato.stanford.edu/entries/relations-medieval/. It should be noted that Scotus' account of real relations breaks away from the traditional thinkers before him. See his, God and Creatures Q3. Also, Peter King, 'Scotus on Metaphysics,' in ed. Thomas Williams, The Cambridge Companion to Duns Scotus (Cambridge: Cambridge University Press, 2003).

70 Eleonore Stump, 'Aquinas' Metaphysics of the Incarnation', in eds. Stephen Davis, Daniel Kendall, and Gerald O'Collins, The Incarnation: An Interdisciplinary Symposium on the Incarnation of the Son of God (Oxford: Oxford University Press, 2002), 203. 
Word. In the incarnation the Word takes on a whole host of properties. Defenders of divine simplicity must explain how a divine person who is simple can have properties and remain simple. It would appear that being simple (having no properties) is incompatible with the communicatio idiomatum. This places divine simplicity in direct conflict with any adequate Christology. ${ }^{71}$

Third, how can a person be an act? The simple God is identical to His act, but this should strike us as implausible. Rogers is clear about this in her defense of divine simplicity. ${ }^{72}$ It is obvious that an act is something a person does and not something a person $i$ s. $^{73}$ It is so obvious that it appears to be a platitude. We will need very good reasons for thinking this platitude is false in order to accept divine simplicity. It should be noted that divine simplicity is concerned with strict metaphysical identity (e.g. A=B). This is not the same as saying that a person's identity is wrapped up in her actions. This latter usage is referring to a sense of self, or character, that she has developed over time through her actions and relations with others. For instance, say I kick you in the stomach. I am not identical to this act, and I did not have to perform this act. Further, you probably wish that I had not performed this act. This act is part of the development of my character, and in this act I take on an enduring property 'having kicked you in the stomach.' This enduring property will forever be a fact about me, and it can be used to identify me. However, I am not identical to this act in the sense of strict metaphysical identity.

Fourth, what do our concepts hang on? God is the source of all the perfections found in creatures. There are multiple perfections that God is said to have, like wisdom and power. These perfections are not identical, and yet they are supposed to be identical in God. How can diverse concepts be identical when they clearly are not? Aquinas responds by denying that these perfections are synonymous since they are found diversely in creatures. ${ }^{74}$ Yet this does not answer the question. We already know that the perfections are diverse in creatures. This is how we were able to come up with distinct abstract perfections. What we want to know is how they can be identical in God. We also want to know what extramental foundation in God grounds the diversity of the

\footnotetext{
71 For more on this see Thomas Senor, 'The Compositional Account of the Incarnation' Faith and Philosophy 24 (2007). Also, Anna Marmodoro and Jonathan Hill (eds), The Metaphysics of the Incarnation (Oxford: Oxford University Press, 2011).

72 Rogers, 'The Traditional Doctrine of Divine Simplicity', 172.

73 Gregory of Nazianzus, The Theological Orations, 3.6.

74 Summa Theologiae, I. q 13, a. 4.
} 
perfections. Aquinas does not help us with these questions. ${ }^{75}$ John Duns Scotus found Thomistic answers of this sort woefully inadequate and offered his formal distinction as a remedy to the problem. But Scotus was criticized for abandoning divine simplicity since he introduced diversity in God. Defenders of divine simplicity must offer an account of how the distinct perfections apply to God without being synonymous to each other. ${ }^{76}$ What is at stake in this issue is the ability to know anything at all about God. If none of our concepts apply to God at all, divine revelation is impossible. Further, simplicity is meant to make reality intelligible by having God as the source of all perfections. If simplicity cannot answer these questions it fails to make reality intelligible, and as such it is utterly useless for Christian theology.

Finally, divine simplicity is said to be incompatible with any unified theory of predication that appeals to exemplifiables. ${ }^{77}$ In Michael Bergmann and Jeffrey Brower's defense of divine simplicity they argue divine simplicity is incompatiblewith anyunified theory of predication such asPlatonism, Augustinianism, Aristotelianism, and immanent realism. In other words, one cannot believe in simplicity and also hold to a realist metaphysic of properties. In fact, one cannot even hold to a nominalist trope metaphysic either. Part of their argument depends on the controversial theory of truthmakers. ${ }^{78}$ A full critique of this position will have to wait for another paper. ${ }^{79}$ For now I will simply note that

75 Nor do Stump and Kreztmann in 'Absolute Simplicity,' 356-7. They explain the diversity of the attributes in terms of the temporal manifestation of God's acts as well as creaturely relations to God. This fails on two fronts. First, it defends timeless acts with temporal effects by way of an analogy that involves a temporal act with a temporal effect. Second, it assumes that God is really related to creation. This is something that divine simplicity cannot allow for.

76 Anders Kraal argues that the available systems of logic do not allow for such a thing without introducing diversity into God in "Logic and Divine Simplicity," Philosophy Compass 6 (2011): 282-294.

77 Michael Bergmann and Jeffrey Brower, 'A Theistic Argument Against Platonism (and in Support of Truthmakers and Divine Simplicity)', in ed. Dean W. Zimmerman, Oxford Studies in Metaphysics Volume 2 (Oxford: Oxford University Press, 2006).

78 For more on truthmaker theory see Gonzalo Rodriquez-Pereyra, 'Truthmakers', Philosophy Compass 1 (2006). D.M. Armstrong, Truth and Truthmakers (Cambridge: Cambridge University Press, 2004). Trenton Merricks, Truth and Ontology (New York: Oxford University Press, 2007).

79 At the moment I shall simply note what I find to be mysterious about the truthmaker defenses of divine simplicity. The truthmaker defense of simplicity holds that God is the truthmaker for all the things we wish to predicate of Him. For instance, the truthmaker for $<$ God is good $>$ is the divine essence. But here is the unexplained mystery. In standard instances of truthmaking, the truthmaker for a proposition is the substance and the property it bears. For instance, the truthmaker for $<$ Socrates is good $>$ is the substance 'Socrates' and the property 'good' that Socrates bears. What is doing the truthmaking in the instance of a simple God? A simple God has no properties, so how could a simple God serve as the truthmaker for the proposition 
this is a radical entailment from divine simplicity, and contemporary theologians should be aware of this before jumping on the simplicity train. Also, as noted above, simplicity is meant to make reality intelligible and cutting us off from unified realist accounts of metaphysics does not help with this endeavor. Even further, it cuts us off from one of the main arguments for divine simplicity: participation in God. The arguments from participation in God assume a unified realist metaphysic. ${ }^{80}$

These final considerations are merely a list of some of the difficulties that arise from simplicity. These are problems that do not have satisfactory answers at the moment. Theologians must be aware of these issues when articulating and defending divine simplicity. These are issues that will need to be fleshed out in greater detail in order for the debate to continue. Ultimately, the defender of divine simplicity must answer the main objection of this paper: simplicity is not a possible perfection because it is not compossible with who God is. ${ }^{81}$

$<$ God is good $>$ ? This sort of explanation is lacking in the literature. See W. Matthew Grant, 'Divine Simplicity, Contingent Truths, and Extrinsic Modes of Divine Knowing,' Faith and Philosophy 29 (2012). Alexander R. Pruss, 'On Two Problems of Divine Simplicity,' in Oxford Studies in Philosophy of Religion Volume 1.

80 Brian Leftow, 'Is God an Abstract Object?' Nous 24 (1990): 581-598, and 'Divine Simplicity,' Faith and Philosophy 23 (2006): 365-380.

81 This discussion brings up an important question for all theologians interested in this debate. According to Graham Cole, 'A good test of any doctrine is to ask what is lost if the doctrine were abandoned.' Graham A. Cole, God the Peacemaker: How Atonement Brings Shalom (Downers Grove: InterVarsity Press, 2009), 157. What, if anything is lost by getting rid of divine simplicity? As far as I can tell what is lost is unnecessary incoherence within Christian theology. One might be concerned that this will require one to offer a completely new understanding of God. In fact, that is a major theme in contemporary Christian theology. Elsewhere I have begun to address this issue. See my, 'Divine Perfection and Creation,' The Heythrop Journal (forthcoming). 